\title{
Chromosome Numbers in the Scilleae
}

\author{
J. M. J. de Wet \\ Division of Botany, P. O. Box 994, Pretoria, South Africa
}

Received March 2, 1957

Cytological data often provide clues to the true relationships of taxonomic units. Lewitsky $(1931 \mathrm{a}, \mathrm{b})$ indicates how the karyotype may be applied taxonomically to any systematic unit. That there is a close correlation between morphological and cytological characters has been demonstrated in numerous genera and larger taxonomic units. The most outstanding example is the monograph of Babcock (1947) on the genus Crepis. In this genus a remarkable range of morphological types exist, extending almost continuously from primitive to advanced. Along with this morphological evidence for progressive evolution is also found an orderly progression in the modification of chromosome number and morphology.

The chromosome numbers of members belonging to the tribe Scilleae (Liliaceae) have been studied. These cytological data are correlated, where possible, with morphological observation.

\section{Material and method}

The material was collected in the veld and cultivated on the Prinshof Experiment Station. Herbarium material together with corresponding cytological slides are filed in the National Herbarium, Pretoria. Slides were prepared by Mr. J. A. Retief, of this office.

Root tips were fixed in Randolp's (1935) fluid for 24 hours, dehydrated in the usual manner and embedded in a paraffin-beeswax-rubber mixture. Sections were cut 18 microns thick and stained according to the method outlined by Stockwell (1934).

For meiotic observations, young inflorescences were fixed in $3: 1$ absolute ethyl alcohol and propionic acid for 24 hours. Anthers were squashed in propiono-carmine after Swaminathan, Magoon and Mehra (1954). Slides were made permanent as was indicated by McClintock (1929). Drawings were made with the aid of a camera lucida. The averages of 5 metaphase plates were used to construct the karyotypes. The magnification is $\times 4200$.

\section{Results and discussions}

The chromosome numbers counted are summarized in Table 1. The genera are treated in more detail later in the discussion. 


\begin{tabular}{|c|c|c|c|c|c|}
\hline Name & Origin & No. & $2 n$ & Fig. & Authority \\
\hline $\begin{array}{l}\text { E. pole-evansii N. E. Br. } \\
\text { Drimiopsis Lindl. }\end{array}$ & Barberton & 796 & 50 & 28 & \\
\hline $\begin{array}{l}\text { D. saundersiae Baker } \\
\text { D. crenata v. d. Merwe }\end{array}$ & $\begin{array}{l}\text { Zululand } \\
\text { Pretoria }\end{array}$ & $\begin{array}{l}689 \\
821\end{array}$ & $\begin{array}{l}20 \\
20\end{array}$ & $\begin{array}{l}27 \\
73\end{array}$ & \\
\hline Pseudogaltonia Kuntz & & & & & \\
\hline $\begin{array}{l}\text { P. clavata (Baker) Phill. } \\
\text { Rhadamanthus Salisb. }\end{array}$ & Windhoek & 814 & 24 & 29 & \\
\hline $\begin{array}{l}\text { R. convallarioides Salisb. } \\
\text { Ornithogalum Linn. }\end{array}$ & Lockenburg & 1290 & 20 & 30 & \\
\hline $\begin{array}{l}\text { O. thermophylum Leighton } \\
\text { O. alticolum forma }\end{array}$ & $\begin{array}{l}\text { Clanwilliam } \\
\text { Tulbagh }\end{array}$ & $\begin{array}{l}868 \\
388\end{array}$ & $\begin{array}{l}12 \\
12\end{array}$ & $\begin{array}{l}31 \\
32\end{array}$ & \\
\hline O. lacteum Jacq. & S. W. Cape & 424 & 12 & 33 & $\begin{array}{l}32, \\
\text { Nakajima, } \\
1936\end{array}$ \\
\hline O. hermanii Leighton & Ex. Stellenbosch & 425 & 12 & 34 & \\
\hline O. species & Sutherland & 595 & 12 & 35 & \\
\hline O. saundersiae Baker & Barberton & 672 & 12 & 36 & \\
\hline O. karooicum Leighton & Bulshoek & 874 & 12 & 37 & \\
\hline O. karooicum Leigeton & Clanwilliam & 883 & 12 & & \\
\hline O. miniatum Jacq. & Worcester & 993 & 12 & 38 & \\
\hline O. miniatum Jacq. & Tulbagh & 848 & 12 & & \\
\hline $\begin{array}{l}\text { var. vandermerwei (B.) } \\
\text { Leighton }\end{array}$ & Ashton & 951 & 24 & 39 & \\
\hline O. synanthifolium Leighton & Pietermaritsburg & 990 & 12 & 40 & \\
\hline O. zeyheri Baker & Grahamstown & 594 & 12 & 41 & $\begin{array}{l}\text { 12, Neves, } \\
1953 \mathrm{~b}\end{array}$ \\
\hline O. Zeyheri Baker & Vantsdrift & 127 & 14 & & \\
\hline O. thyrsoides Jacq. & Kirstenbosch & 431 & 12 & & $\begin{array}{l}\text { 12, Neves, } \\
\text { 1953a }\end{array}$ \\
\hline O. thyrsoides Jacq. & East London & 1275 & 12 & 42 & \\
\hline O. thyrsoides forma & Piquetberg & 913 & 12 & 43 & \\
\hline O. thyrsoides forma & Clanwilliam & 873 & 12 & & \\
\hline O. flavissimum Jacq. & Sutherland & 1292 & 12 & 44 & \\
\hline O. alticolum Leighton & Tulbagh & 839 & 12 & 45 & \\
\hline O. ecklonii Schlecht. & Bloemfontein & 130 & 12 & 46 & \\
\hline O. prasinum Lindl. & Nylstroom & 126 & 14 & & \\
\hline O. prasinum Lindl. & Lichtenburg & 129 & 14 & & \\
\hline O. prasinum Lindl. & Hammanskraal & 132 & 12 & 47 & \\
\hline O. setifolium Kunth. & Pretoria & 803 & 12 & 48 & \\
\hline O. setifolium Kunth. & Potchefstroom & 1229 & 12 & & \\
\hline O. settfolium Kunth. & Bloubosput & 1002 & 8 & 49 & \\
\hline O. incospicuum Baker & Pilgrimsrest & 991 & 20 & 50 & \\
\hline O. leipoldtii Leighton & Malmesburgy & 925 & 10 & 51 & \\
\hline O. maculatum Thunb. & Clanwilliam & 875 & 14 & 52 & \\
\hline O. maculatum Thunb. & Pakhuisberg & 895 & 14 & & \\
\hline var. speciosum Leighton & Paleisheuwel & 910 & 14 & 53 & \\
\hline var. splendens Leighton & Clanwilliam & 882 & 14 & & \\
\hline O. pretoriens Baker & Donkerhoek & 183 & 50 & 55 & \\
\hline O. sauveolens Jacq. & Van Rhynsdorp & 653 & 36 & 56 & \\
\hline
\end{tabular}


Table 1. Chromosome numbers

Name Origin $\quad$ No. $2 n$ Fig. Authority

Albuca Linn.

A. nelsonii N. E. Br.

A. setosa Jacq.

A. bainesii Baker

A. bainesii Baker

A. transvaalensis Mogg

A. transvaalensis Mogg

A. pachychlamys Baker

A. flaccida Baker

A. canadensis (L.) Leighton

A. canadensis (L.) Leighton

Thuranthos Wright

T. macranthum (Bkr.) Wr.

Urginea Steinh.

U. pretoriensis Baker

$\mathrm{U}$. langii Brem.

U. langii Brem.

U. burkei Baker

U. burkei Baker

U. multisetosa Baker

U. lydenburgensis $R$. A. Dyer

U. altissima Baker

U. tenella Baker

U. depressa Baker

U. rubella Baker

U. epigea R. A. Dyer

U. epigea R. A. Dyer

Galtonia Dcne.

G. viridifolia Verd.

G. princeps Dcne.

Drimia Jacq.

D. haworthioides Baker

D. elata Jacq.

Dipcadi Medic.

D. viride Moench.

D. glaucum Baker

Kimberley

Cultivated

818

817

$\begin{array}{rll}1013 & 20 & 1 \\ 1011 & 20 & 2 \\ 1042 & 20 & 3 \\ 1267 & 20 & \\ 818 & 20 & 4 \\ 1297 & 20 & \\ 1268 & 40 & 6 \\ 872 & 18 & 5 \\ 907 & 18 & 7 \\ 860 & 18 & \end{array}$

1283

20

8

Pretoria

135

192

1271

1270

19520

$811 \quad 20 \quad 11$

$1023 \quad 32 \quad 12$

$1269 \quad 20 \quad 13$

$1042 \quad 20 \quad 14$

$1284 \quad 40 \quad 15$

$134 \quad 42 \quad 16$

$191 \quad 32 \quad 17$

$1022 \quad 32$

Mt, aux-sources

$1043 \quad 16$

18

1043a $\quad 16 \quad 68$

Bathurst

1005

1295

20

19

$18 \quad 20$

Weenen

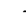

(1)




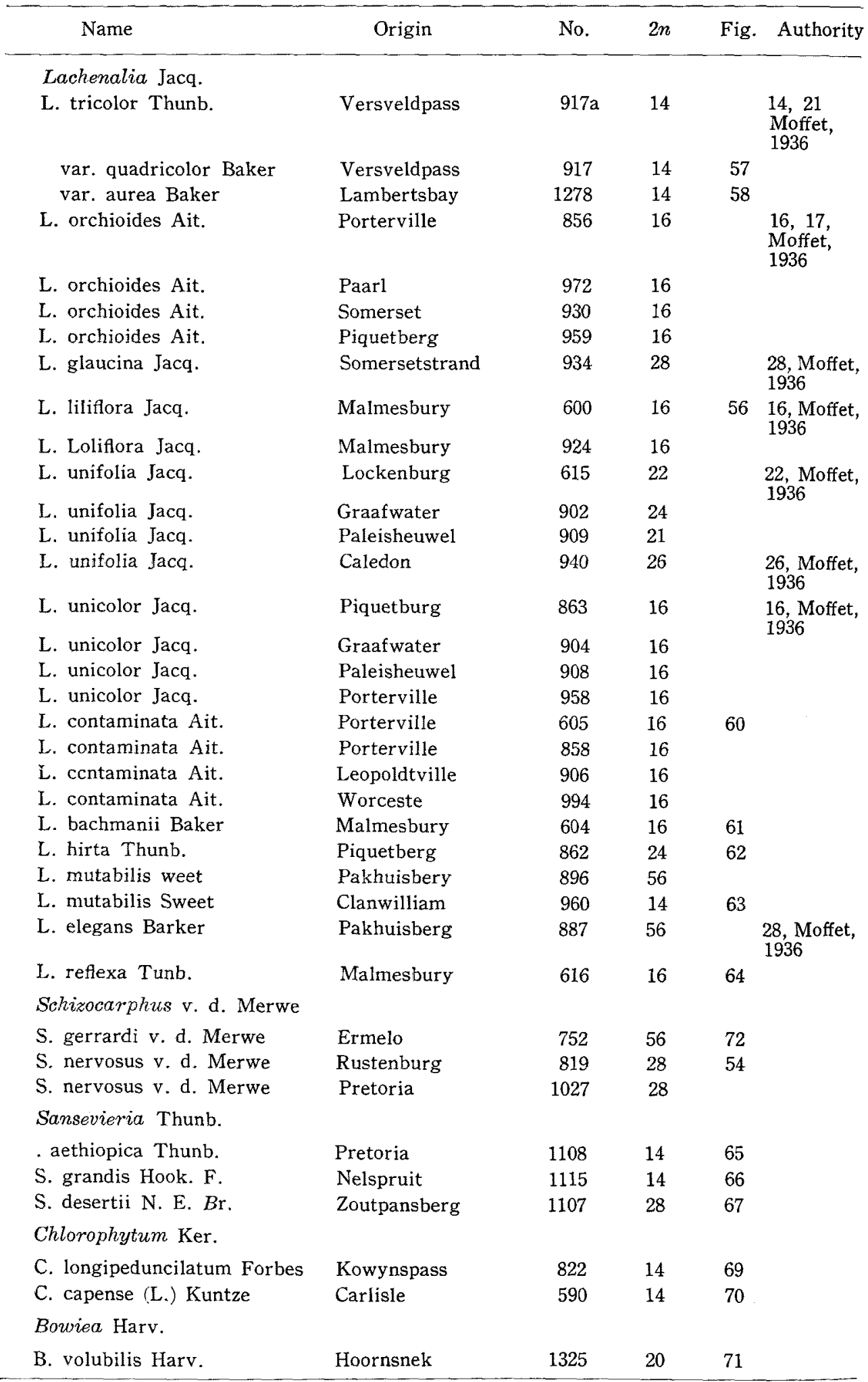


Albuca Linn.: A large genus divided by Baker (1896) into three subgenera. These are distinguished from each other as follows. Leptostyla is characterized by a cylindrical style. The remaining two subgenera have the style prismatic. Subgenus Falconera and subgenus Eualbuca differ from each other in that the latter has the three outer stamens reduced and sterile.

Subgenus Leptostyla includes a single species, A. shawii Baker which was not available for study. Five species of subgenus Falconera were investigated. These are characterized by $2 n=20$ and $2 n=40$. The basic
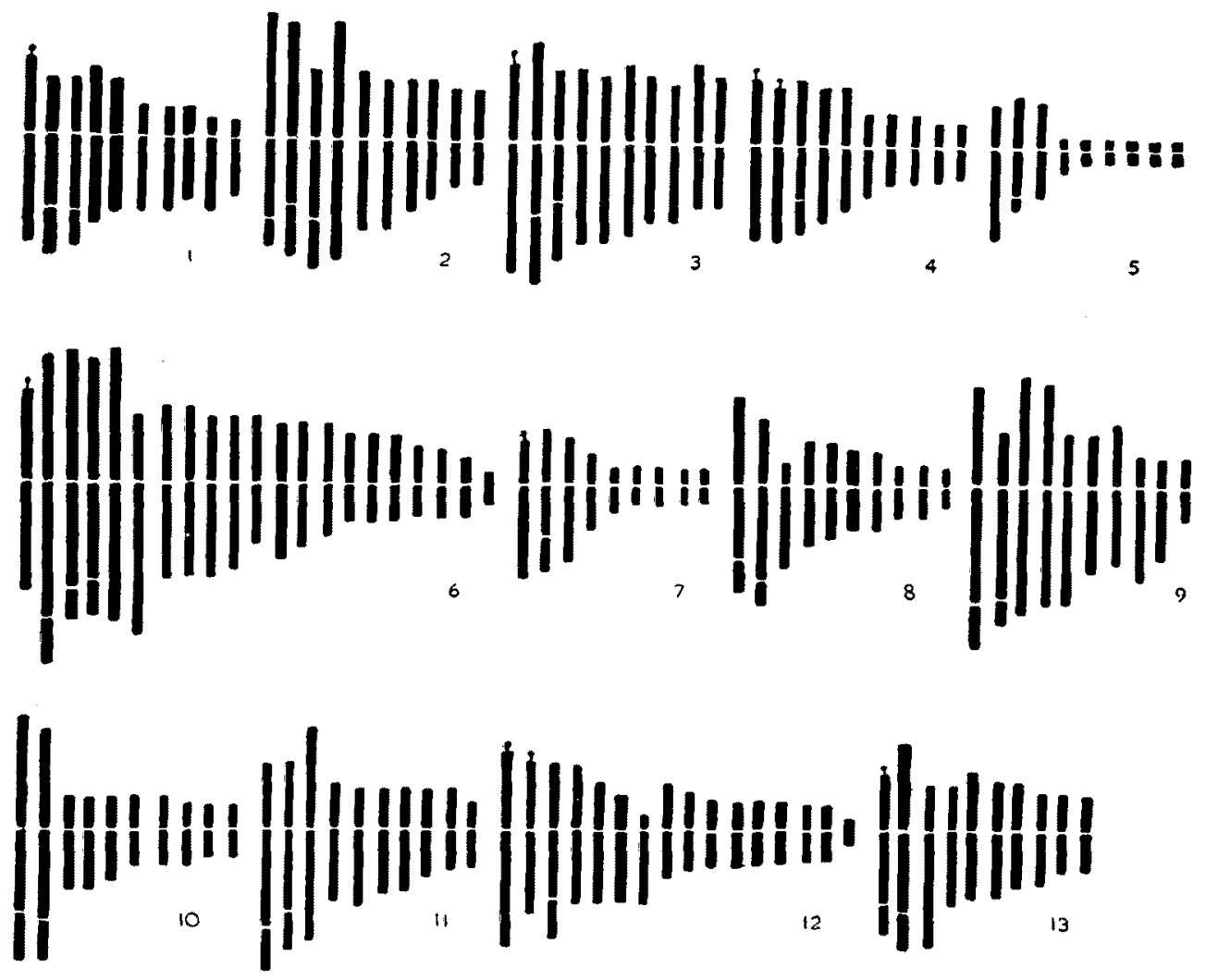

Fig. 1-13

chromosome number appears to be $n=10$. Two species of Eualbuca were studied and found to have $2 n=18$. Here we are dealing with a basic chromosome number $n=9$. The chromosomes of the species studies belonging to the latter subgenus, are much smaller than those of Falconera (compare figures 1-7). Evidently, subgenera Falconera and Eualbuca differ from each other, not only in a prominent morphological character, but also in chromosome number and morphology. Other morphological characters, however, are very similar and the type of variation observed between species in Falconera is also present in Eualbuca. This seems to indicate that they may have had a parallel development from very early in the history of the genus. 
The loss of one chromosome pair in some of the original types could have given rise to Eualbuca. This may have had as a result, the loss of fertility in the three outer stamens. We may then predict that the subgenus Leptostyla, with its three rudimentary anthers, will also be found to have a basic chromosome number of $n=9$. The marked difference in the shape of the style between subgenera Leptostyla and Eualbuca may be the result of a later mutation.

The original basic chromosome number of Albuca appears to be $n=10$, but it is quite possible that this number became established from an earliar number of $n=5$. All the species investigation with $2 n=20$ are characterized by 6 nucleoli during mitotic telophase. The species with $2 n=18$ have only 4 nucleoli. The presence of 6 nucleoli seems to indicate that polyploidy has played a role in the evolution of species with $2 n=20$. It was indicated by Gates (1942) and de Wet (1953) that the most common number of nucleoli encountered in diploids is 2 or 4 . It was also indicated, however, that nucleoli numbers may not always be an indication of the degree of polyploidy.

Thuranthos Wright: An endemic genus described by Wright (1916) to include, originally, only Drimia macrantha Baker. Thuranthos macranthum (Bkr.) Wright is characterized by 20 somatic chromosomes, resembling those of Urginea in many details. Four nucleoli are regularly produced during telophase. In chromosome morphology Thuranthos differ from Drimia very conspicuously.

Urginea Steinh.: Widely distributed throughout Africa, the mediteranean region and India. Fifty-seven species have been described from South Africa (Phillips 1951). Ten of these were studied cytologically. A basic chromosome number of $n=5$ were previously proposed for the genus by Geitler (1928). The same author also indicated the presence of chromosome fragments $(2 n=10+2 f)$ in $U$. maritima. Chromosome numbers of $2 n=20$, 30 and $2 n=40$ were observed in the same species by Raghavan and Venkatasubban (1940) and Sato (1943).

Chromosome numbers of $2 n=20,30,32$ and $2 n=40$ were observed in the South African species studies. Chromosome fragments were regularly observed in the chromosome compliment $U$. rubella with $2 n=40$.

Indications of polyploidy is present in most of the species. Two or more pairs of chromosomes resembling each other are almost always present. Meiotic behaviour, however, has not yet been studied. Nucleoli numbers produced, are either 4 or 6 .

Urginea langii is of special interest. Morphologically it seems to form a steppingstone between the genera Urginea and Ornithogalum. It was described as Urginea but later transferred to Ornithogalum wilmanae by Leighton (1945). Cytologically it differs from other species of Urginea in its larger chromosomes, which in many respects remind one of those of Ornithogalum. The basic chromosome number is $n=10$, a number, although 
commonly found in Urginea, is also present in South African species of Ornithogalum. These cytological observations support Leighton's (1945) conclusion that this species could be classified more naturally with Ornithogalum. Morphologically it possesses the diagnostic character of Ornithogalum, in that the filaments of the stamens are much flattened. On the other hand, the deeply tri-lobed capsule and flattened seeds are typical of the genus Urginea.

Another species with similar morphological characters is $O$. virens Lindl.
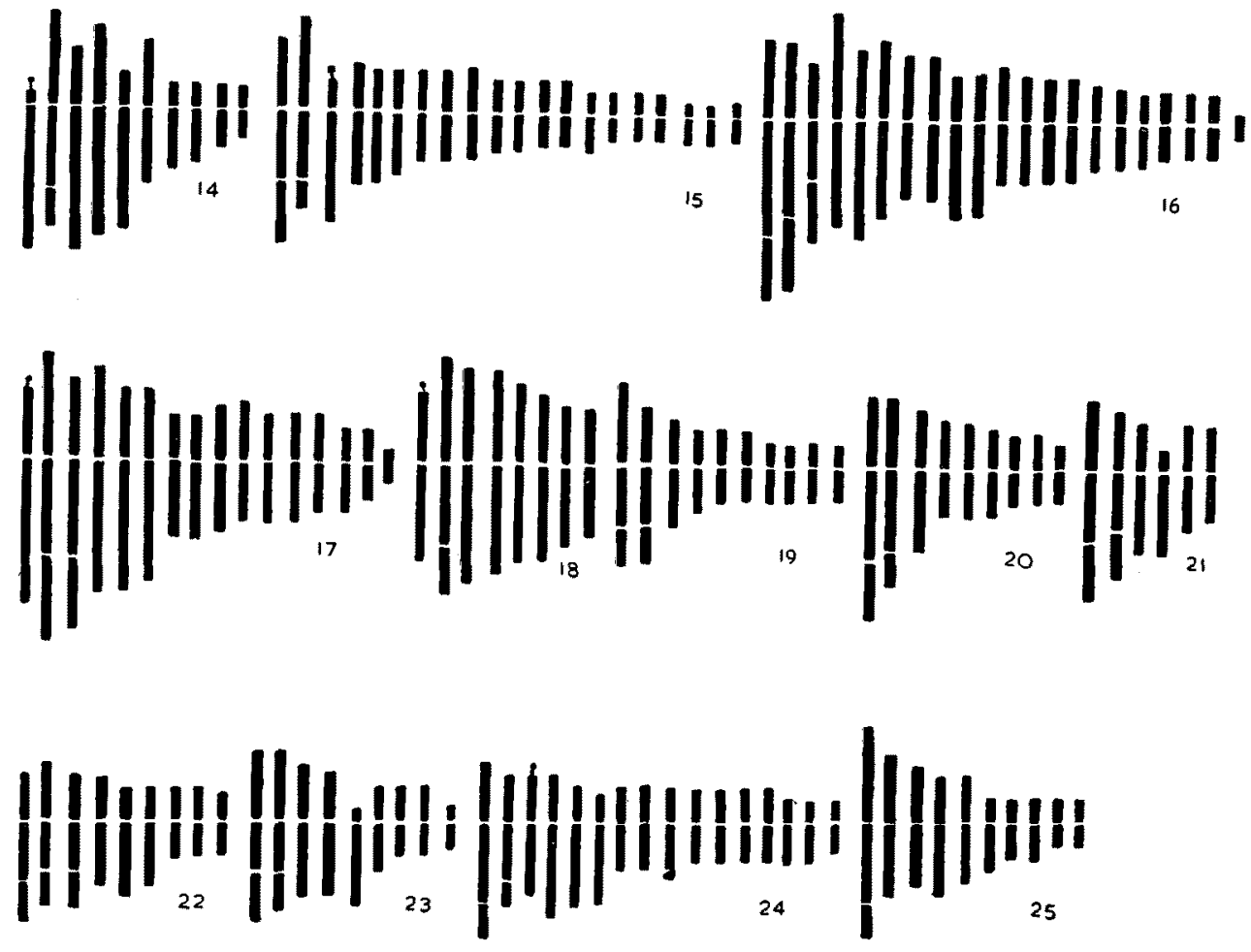

Figs. 14-25

which was discussed by Quintanilha and Cabral (1947). This species was found to have 6 somatic chromosomes resembling those of typical members of Ornithogalum in length.

Two more species of Urginea deserve special mentioning. These, $U$. epigea and $U$. lydenburgensis are characterized by $2 n=32$. It was first thought that the basic chromosome number is $n=15$ and that the additional chromosomes represent fragments as is the case in $U$. rubella. In these two species the two additional chromosomes were observed in all the specimens studied. Morphologically these two species are also rather distinct in bulb structure.

Galtonia Decne.: Small endemic genus. One species, G. candicans has previously been studied by Newton (1924), recording $2 n=16$. A similar 
chromosome number was counted in $G$. princeps and $G$. viridifolia indicating a basic chromosome number of $n=8$.

Drimia Jacq.: An African genus with 26 species in South Africa. Only two have been studied cytologically. They differ from each other in chromosome number: D. haworthioides has $2 n=20$ and $D$. elata has 18 somatic chromosomes.

Dipcadi Medic.: A large genus mostly confined to Africa. Only two species were available for study. La Cour (Darlington and Janaki Ammal, 1945) demonstrated $2 n=18$ in $D$. glaucum. This count has been varified. A chromosome number of $2 n=12$ was observed in $D$. viride. Still a third chromosome number of $2 n=8$ was counted by Levan (1943) in the mediterranean species $D$. serotinum. Basic chromosome numbers of $n=4,6$ and 9 have thus been observed.

Scilla Linn.: A large genus with a wide distribution. Many European and Oriental species have already been studied and an aneuploid series of basic number $(n=4,6,7,8,9,10$ and 11) became evident (Sato, 1942, Maude, 1940, Battaglia $1952 \mathrm{a}, \mathrm{b})$. The two species here investigated, S. firmifolia and $S$. natalensis are characterized by $2 n=18$ and $2 n=36$ respectively.

Schizocarphus v. d. Merwe: This genus has recently been removed from Scilla on the basis of prominent morphological characters. Cytologically they differ from each other prominently in that this new genus has much smaller chromosomes than those characteristic of Scilla. Chromosome numbers of $2 n=58$ (Meiotic metaphase with $n=28$ ) and $2 n=28$ were observed. The basic chromosome number of these two species is $n=14$. The much smaller chromosomes characteristic of Schizocarphus leads one to wonder whether this genus is really as closely related to Scilla as it was previously thought.

Eucomis L'Herit: An African genus of 14 species, 7 of which are known cytologically. Matsuura and Sutô (1935), Satô (1942) and Koeperich (1930) demonstrated $2 n=30$ in $E$. bicolor and $E$. undulata, whereas $E$. punctata and D. pallidiflora are characterized by $2 n=60$. The chromosome numbers reported for $E$. undulata and $E$. punctata have been confirmed. For $E$. bicolor a second chromosome number of $2 n=32$ has been reported by Darlington (1926). Three species have been investigated for the first time. These are characterized by chromosome numbers; $2 n=20$ ( $E$. vandermerwe $i$ ), $2 n=30$ (E. regia) and $2 n=50$ (E. pole-evansii). The first mentioned species is a small plant less than a foot high whereas $E$. pole-evansii is an extremely large plant.

The presence of a somatic chromosome number of $n=20$ seems to indicate that the other species are polyploids based on $n=10$. The triploid species $(2 n=30), E$. regia, however, is characterized by a regular meiotic behaviour, indicating that allopolyploidy must have played a role in species evolution and that the original basic chromosome number could have been $n=5$. 
Drimiopsis Lindl.: A relatively small genus with nine species recorded from South Africa. Two species were studied, both characterized by 20 somatic chromosomes.

Pseudogaltonia Kuntze: This monotypic genus was included in Galtonia by Baker (1896). Floral characteristics, however, lead to the description of a new genus Pseudogaltonia Kuntze. Cytologically they further differ in that Galtonia is characterized by $n=8$ and Pseudogaltonia by $n=12$.
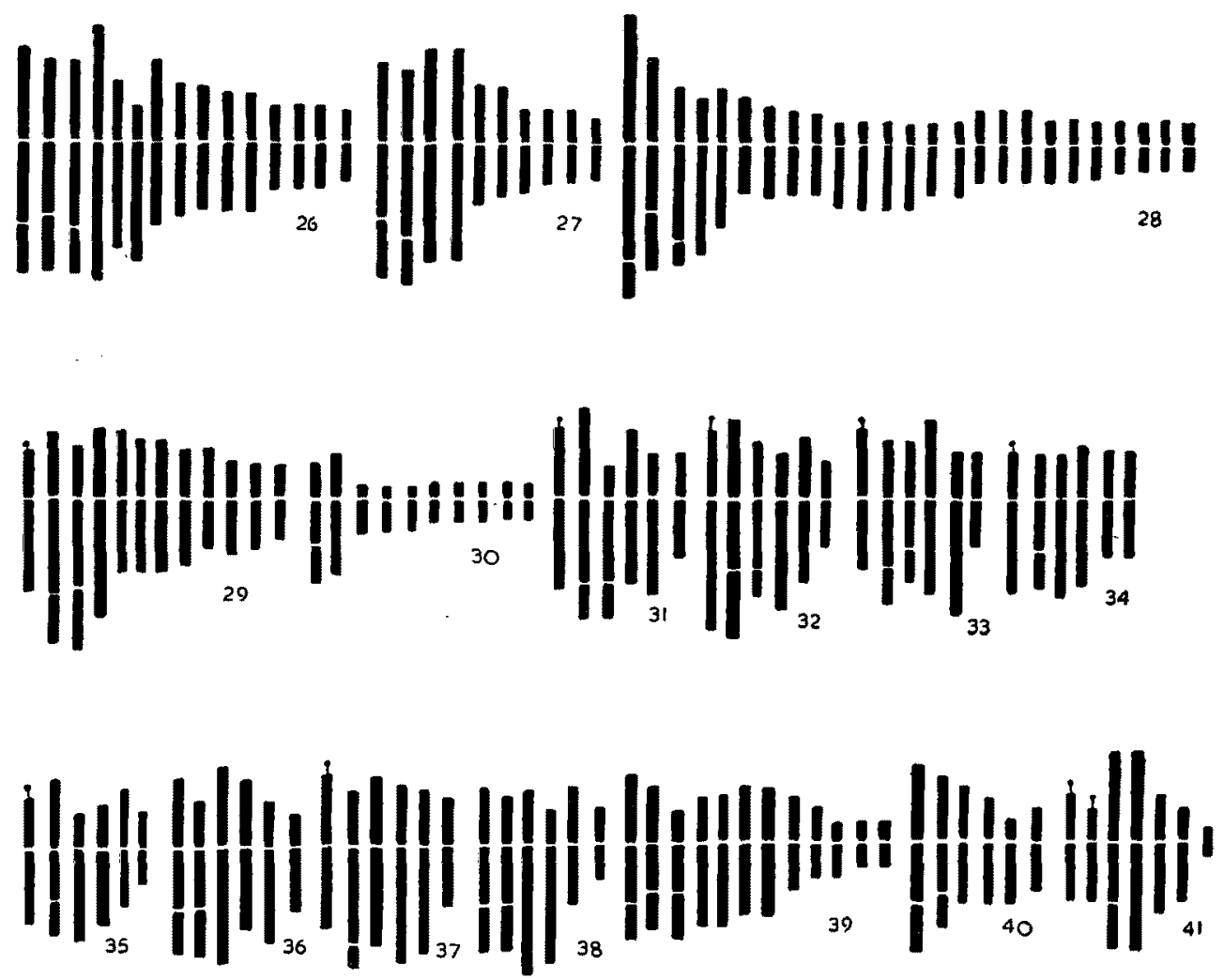

Figs. 26-41

Rhadamanthus Salisb.: An endemic genus with two or three species. The type species $R$. convallarioides has been studied cytologically and found to have $2 n=20$. The chromosomes of this species are characteristic. Two chromosome pairs are relatively long and the remaining eight pairs extremely short (figure 30).

Ornithogalum Linn.: The cytology of the European species of this genus have been studied by a number of workers. Most outstanding is the work of Neves (1952) who summarized all the available cytological data. Further studies were reported by Neves (1953 a and $1953 \mathrm{~b})$. The species were subdivided by Baker (1896) into four subgenera. The South African representatives were studied morphologically by Leighton (1944a, b and 1945) and a complete revision was presented. This new revision was followed in the identification 
of the species. The majority of the species are characterized by 12 somatic chromosomes, indicating a common chromosome number of $n=6$. A number of species with $n=6$, however, are characterized in some specimens by an extra chromosome pair. These are $O$. zeyheri, O. ecklonii and $O$. prasinum. Morphologically these chromosome races cannot be distinguished and the extra chromosome pair evidently has little effect on the phenotypic appearance of the species. Two chromosome races were also encountered in O. setifolium. Here the $2 n=12$ from is small whereas the $2 n=8$ form is more robust. Floral
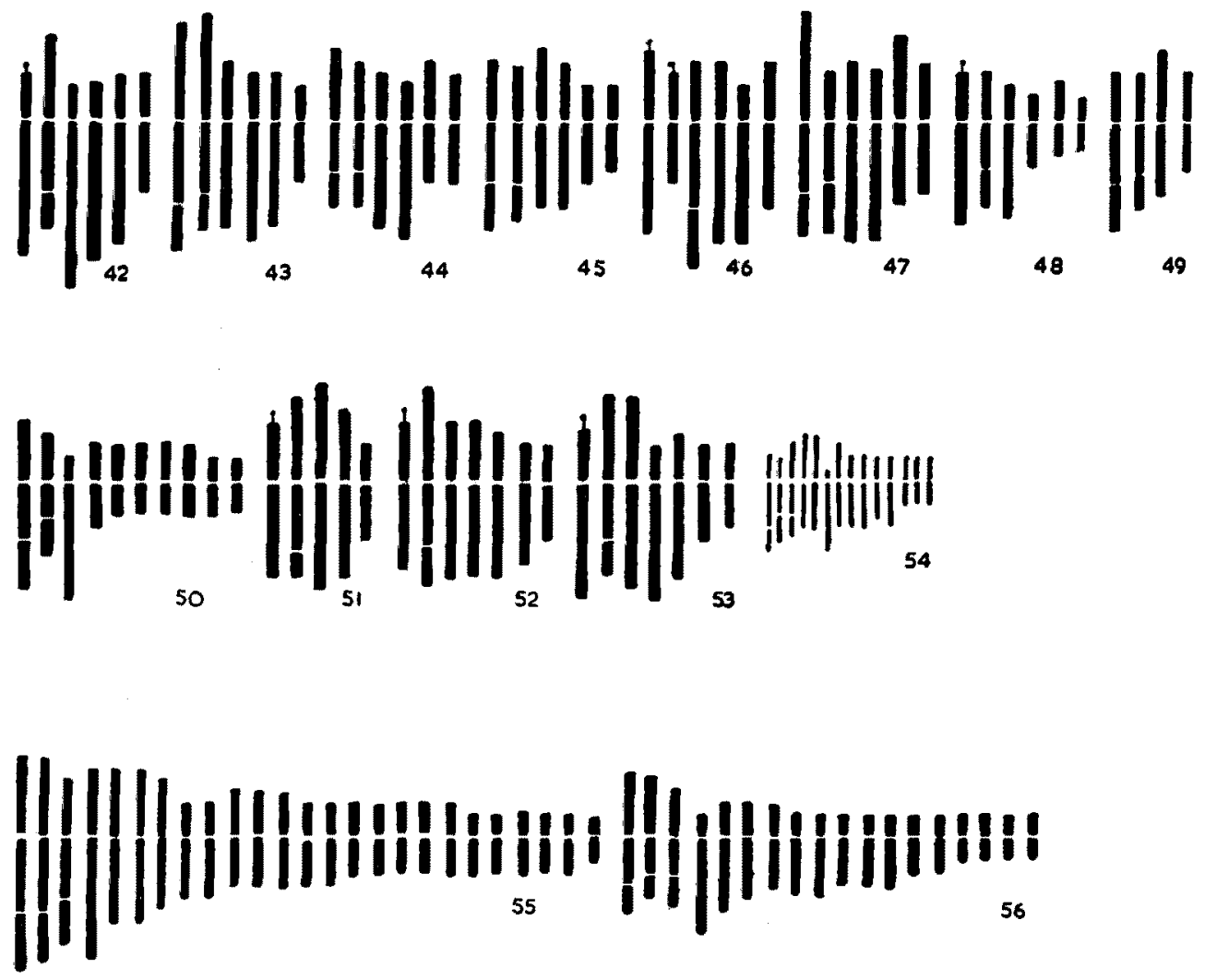

Figs. $42-56$

morphology, however, is similar in these two forms.

One species, $O$. maculatum together with its two varieties, var. speciosum and var. splendens is characterized by $2 n=14$. The extra chromosome pair has apparently been incorporated into the normal chromosome compliment. Three species with a basic chromosome number of $n=5$ have also been encountered. All of these seem to show relationships with the genus Urginea, both cytologically as well as morphologically. Ornithogalum sauveolens also resembles the genus Urginea in some minor morphological characters but differs from this genus both in chromosome number and general chromosome morphology. 
The varieties of some of the species studied differ from each other vary conspicuously in chromosome morphology. This is especially obvious in $O$. alticolum forma (figure 32) and O. alticolum proper (figure 45) and $O$. thyrsoides (figure 42) and $O$. thyrsoides forma (figure 43). Cytological observations seem to indicate that, these particular forms at least, may be worthy of subspecies or even species rank. Morphologically these forma are distinct, to some extent at least, from the typical species in gross morphological appearance. This is also true in the two chromosome races of $O$. setifolium.
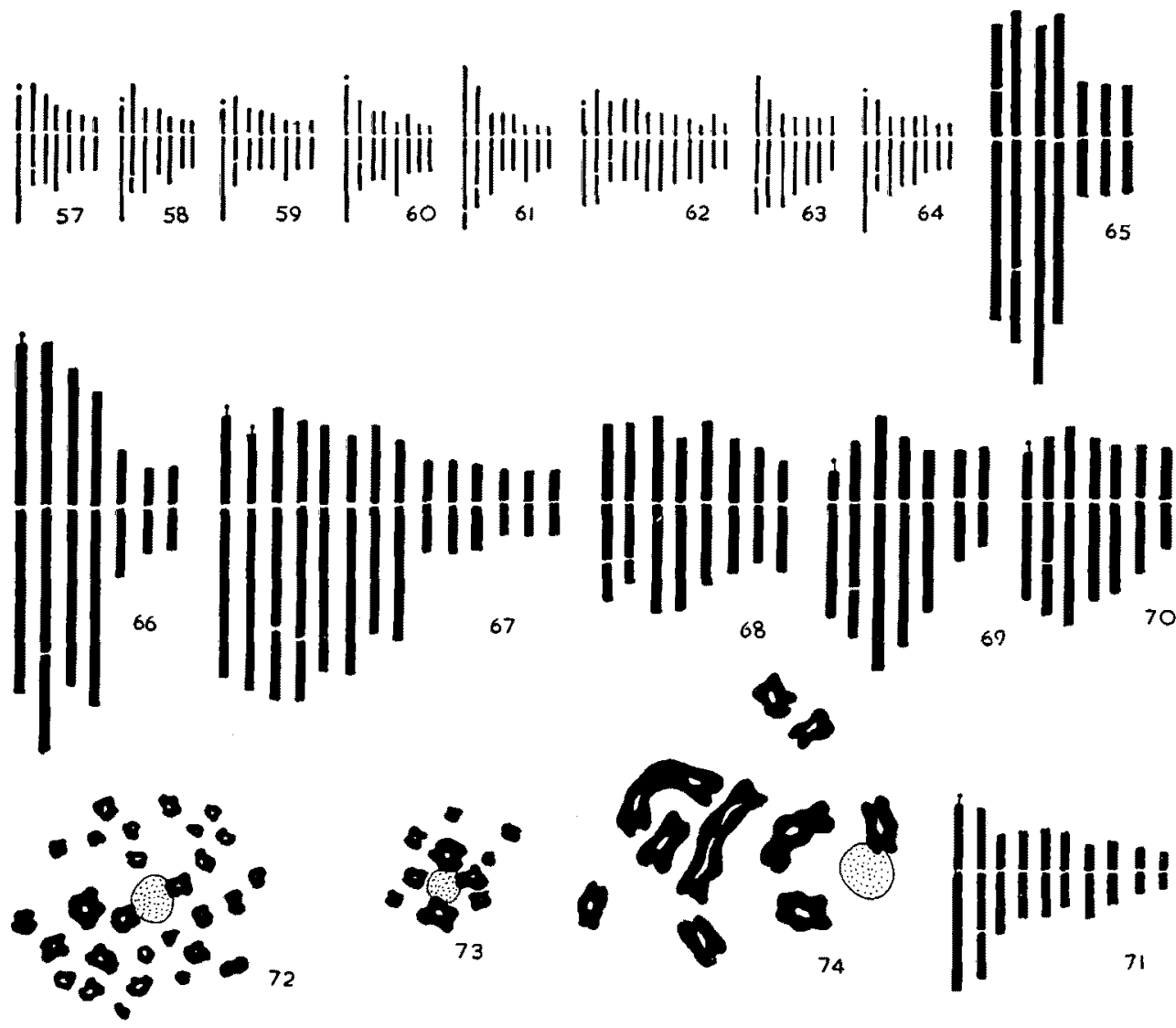

Figs. $57-74$

Ornithogalum miniatum and its variety vandermerwei differ from each other in chromosome number. The latter being a tetraploid. Chromosome morphology, however, definitely proves that the variety must be of allopolyploid origin, rather than of an ordinary chromosome doubling.

Lachenalia Jacq.: An endemic genus of sixty-five species concentrated mostly in the south-western district of the Cape. Baker (1896) divides this genus into five subgenera as follows. A cylindrical perianth and dimorphic segments are characteristics of Eulachenalia. Subgenus Erachyscypha differ from the first mentioned in having nearly uniform segments. The perianth 
in the remaining three subgenera is not cylindrical. It is oblong-cylindrical in Orchiops, campanulate and oblong-campanulate in Chloriza ; and ventricate, oblique at the base in Coelanthus.

This genus together with Schizocarphus is characterized by chromosomes which are smaller in length and circumference than those of other members belonging to the Scilleae.

Eulachenalia: Three species are inculded by Baker (1896) all of which were studied cytologically by Moffet (1936). All these species are characterized by a basic chromosome number $n=7$. Two varieties of L. tricolor: var. aurea and var. quadricolor were also found to have $n=7$. They differ from each other very little in chromosome morphology (figures 57 and 58).

Brachyscypha: The single species, L. pusilla, is not known cytologically.

Orchiops: Three of the species, $L$. orchioides $(2 n=16,17), L$. glaucina $(2 n=28)$ and L. liliftora $(2 n=16)$ were studied by Moffet (1936). Two basic chromosome numbers, $n=7$ and $n=8$, are evident. Four collections from different localities of $L$. orchioides $(2 n=16)$, two of L. liliflora $(2 n=16)$ and one of L. glaucina $(2 n=28)$ were studied and chromosome numbers similar to those previously reported were observed.

Chloriza: This subgenus includes the majority of species. Moffet (1936) studied L. unifolia $(2 n=22,26), L$. rosea $(-n=14) L$. pallida $(2 n=16)$, L. purpureo-caerula $(2 n=16)$, L. unicolor $(2 n=16)$ and L. nervosa $(2 n=16)$. This indicated basic chromosome numbers of $n=7,8,11$, and 13. Four collections of $L$. unifolia were studied, each with a different somatic chromosome number namely $2 n=21,22,24,26$. The presence of a plant with $2 n=21$ seems to indicate that triploidy may have played a role in the origin of the species. Abnormal chromosome pairing and random distribution to the gametes, commonly found in triploids, may have given rise to the different chromosome numbers observed. Meiosis, however, has not yet been studied in this triploid plant.

A number of other species were studied for the first time (table 1). These are characterized by basic chromosome number of $n=7,8$ and 12 . Lachenalia hirta has $2 n=24$, and may also be derived from an original triploid plant on the basis of $2 n=7$. A diploid plant $(2 n=14)$ and one with $2 n=56$ were observed for L. mutabilis. Morphologically these plants cannot be distinguished.

Coelanthus: Includes a single species, L. reflexa with $2 n=16$.

It becomes quite evident that the subdivision of the genera in respect to basic chromosome number does not coincide with the morphological subdivision of Baker (1896). A morphological revision of the genus to fit in with the cytological data may be possible. Before this is attempted, a more complete picture of chromosome numbers in the genus should be available.

The remaining genera belonging to the Scilleae with representative in South Africa were not available for study. These are Urgineopsis Compton, 
Litanthus Harv., Hyacinthus Linn., Veltheimia Gled. and Massonia Thunb. et. al. Of special interest is the latter, of which Phillips (1951) notes that, "the genera Massonia, Polyxena, Neobakeria, Whiteheadia, Androsiphon and Amphisiphon would repay careful re-examination. All agree in having connate stamens and it is probable that further study would reduce the species to one or two well defined genera". Karyological studies may help to determine the generic limits. A number of genera are not represented in South Africa. These are Cammasia, Chionodoxa, Rhodocodon, Muscari and Puschkinia. Some of the genera not studied in the present investigation are known cytologically. These are listed by Darlington and Janaki Ammal (1945), and are characterized by the following basic chromosome numbers. Camassia $(n=15)$, Chionodoxa $(n=9)$, Hyacinthus $(n=4,8$ and 14$)$, Muscari $(n=9)$ and Puschkinia $(n=5)$. A basic chromosome of $n=5(n=10,15)$ is present in 7 of the 18 genera known cytologically. A similar number is also present in some species of two more genera. Other chromosome numbers may be regarded as polyploids or diploids on the basis of $n=6,7,8$ and 9 . Hybridization and allopolyploidy could have given rise to the basic numbers of $n=11$ and $n=13$ which are also present. Basic chromosome numbers of $n=3$ and 4 which were also observed may be the result of chromosome reductions from original types with $n=5$.

A number of genera were studied which do not belong to the Scilleae. Sansevieria is placed by Baker (1896) in the Moderaceae, Hutchunson (1934) in the tribe Draceaeneae (family Agavaceae) but Phillips (1951) in the Liliaceae. This genus is characterized by large chromosomes and the South African species studied by $n=7$ Darlington and Janaki Ammal (1945) list basic chromosome numbers of $n=20$ and 21 in tropical African and Oriental species.

Chlorophytum, tribe Asphodeleae (Liliaceae) were also studied and found to have a basic chromosome number of $n=7$. A similar number was previously reported by Yamazaki (1936). Bowiea belonging to the Liliaceae, tribe Bowieae is characterized by a basic number of $n=10$. This genus was previously studied by D'Amato (1949).

\section{Summary}

The cytology of a number of genera belonging to the tribe Scilleae was investigated. Six genera and 68 species and varieties were previously unknown cytologically. The chromosome number is also reported in some species belonging to 3 genera not included in the Scilleae. The genera which were investigated, cytologically for the first time, are Albuca $(n=9)$, $10)$, Thuranthos $(n=10)$, Pseudogaltonia $(n=12)$, Rhadamanthus $(n=10)$, Drimia $(n=9,10)$ and Schizocarphus $(n=14)$. The relationships between the genera were pointed out where possible. The original basic chromosome number for the tribe Scilleae has been postulated as being $n=5$. 


\section{Literature cited}

Babcock, E. B. 1847. The genus Crepis. Univ. Calif. Publ. Bot. vols. 21 and 22: 1-1033. Bakers, J. G. 1896. Liliaceae. Flora Capensis 6:253-528.

Battaglia, E. 1952 a. Filogenesi del cariotipo nel genere Scilla. 2. I1 cariotipo di $S$. autumnalis L., Soc. Toscana Sci. Nat. LIX: 130-145.

- 1952 b. Filogenesi del cariotipo nel genera Scilla. 3. Scilla oblusifolia Poir. var. intermedia (Guss) Bak., Soc. Toscana Sci. Nat. LIX: 146-161.

D'Amato, F. 1949. Studio citologico ed embriologico di Bowiea volobulis Harv,. Caryologia 2: $60-70$.

Darlington, C. D. 1926. Chromosome numbers in the Scilleae. Journ. Genetics 16: 237-281.

- and Janaki Ammal, E. K. 1945. Chromosome atlas of cultivated plants. George Allen and Unwin Ltd. London. $396 \mathrm{pp}$.

de Wet, J. M. J. 1953. Nucleoli numbers in Danthonia polyploids. Cytologia 18: 229-234. Gates, R. R. 1942. Nucleoli and related nuclear structures. Bot. Rev. 8: 337-409.

Geitler, L. 1929. Züchter 1:243. Quoted by Darlington and Janaki Ammal, 1945.

Hutchinson, 1934. Liliaceae. The families of flowering plants 2: 81-102.

Koeperich, J. 1930. Cellule 39: 307. Quoted by Darlington and Janaki Ammal, 1945.

Leighton, F. M. 1944 a. A revision of the South African species of Ornithogalum L. 1. So. Afr. Journ. Bot.

- $1944 \mathrm{~b}$. A revision of the South African species of Ornithogalum L. 2. So. Afr. Journ. Bot. 10:83-110.

- 1945. A revision of the South African species of Ornithogalum L. 3. So. Afr. Journ. Bot. 11: 111-122.

Levan, A. 1943. The pigment content of polyploid plants. Hereditas 29: 255-268.

Lewitsky, G. A. 1931 a. The karyotype in systematics. Bull. Appl. Bot. 27: 187-240.

- 1931 b. The morphology of chromosomes. Bull. Appl. Bot. 27: 19-174.

Matsuura, H. and Sutô, T. 1935. Contributions to the idiogram study in Phanerogramous plants. Journ. Fac. Sci. Hokkaido, Univ. 5: 33-76.

Maude, P. F. 1940. A list of chromosome numbers of species of British flowering plants. New Phytol. 38: 1-31.

McClintock, B. 1929. A method for making aceto-carmine smears permanent. Stain Tech. 4: $53-56$.

Moffet, A. A. 1936. Cytologia 4:490. Quoted by Darlington and Janaki Ammal, 1945.

Nakajima, G. 1936. Chromosome numbers in some crops and wild Angiospermis. Jap. Jour. Genetics 12: 211-218.

Neves, J. de B. 1952. Estudos cariologicos no genero Ornithogalum L,. Dissertacao da Fac. Cien. Univ. Coinbra: 1-192

- 1953 a. Sobre a cariologia de Ornithogalum thyrsoides Jacq,. Cienc. Madrid 18: 1-19.

- 1953 b. Sobre a emparelhomento somatico em Ornithogalum zeyheri Baker. Cienc. Madrid 19: 826-937.

Newton, W. C. F. 1924. Studies on somatic chromosomes. 1. Pairing and segmentation in Galtoria. Ann. Bot. 38: 197-206.

Phillips, E. P. 1951. The genera of South African flowering plants. Bot. Survey So. Afr. memoir 25: 176-196.

Quintanilha, A. and Cabral, A. 1947. A new species of Liliaceae with six somatic chromosomes. So. Afr. Journ. Sci. 43: 167-170.

Raghawan, T. S. and Venkatasubban, K. R. 1940. Cytologia 11:55. Quoted by Darlington and Janaki Ammal, 1946.

Randolph. L. F. 1935. A new fixing fluid and a revised schedule for the paraffin method in plant cytology. Stain Techn. 10: 95-96.

Satô, D. 1942. Karyotype alteration and phylogeny in Liliaceae and allied families. Jap. Journ. Bot. 12: 57-161. 
Stockwell, P. 1434. A stain for difficult plant material. Science 80: 121-122.

Swaminathan, M. S. Magoon, M. L. and Mehra, K. L. 1954. A simple propionic-acid carmine smear method for plants with small chromosomes. Indian Journ. Genet. Plant Breed. 14: 87-88.

Wright, C. H. 1916. Thuranthos. Kew Bull. 1916: 233-234.

Yamazaki, R, 1936. Jap. Journ. Genet. 12: 551. Quoted by Darlington and Janaki Ammal, 1945. 